\title{
Relation Between Cigarette Smoking and Sarcopenia: Meta-Analysis
}

\author{
M. STEFFL ${ }^{1}$, R. W. BOHANNON ${ }^{2}$, M. PETR ${ }^{1}$, E. KOHLIKOVA ${ }^{1}$, I. HOLMEROVA ${ }^{3}$ \\ ${ }^{1}$ Faculty of Physical Education and Sport, Charles University, Prague, Czech Republic, ${ }^{2}$ Physical \\ Therapy Program, Department of Kinesiology, University of Connecticut, Storrs, CT, USA, ${ }^{3}$ Centre \\ of Expertise in Longevity and Long-Term Care, Faculty of Humanities, Charles University, Prague, \\ Czech Republic
}

Received April 8, 2014

Accepted November 4, 2014

On-line December 22, 2014

\begin{abstract}
Summary
Cigarette smoking is a risk factor for many diseases. It could be associated with sarcopenia. The aim of this meta-analysis was to determine whether smoking is an isolated risk factor for sarcopenia. We searched PubMed, Web of Science, EBSCO, and Science Direct for articles addressing the relationship between cigarette smoking and sarcopenia. A total of 12 studies containing information on 22,515 participants were included in this meta-analysis. Odds ratio (OR) was calculated for each study group and for all studies together. An OR was also calculated separately for each sex. We used a fixed-effect model in overall estimation and in males, because results of small studies were significantly different from the results of large studies in those cases and in females where the estimation showed only moderate heterogeneity we used a random-effect model. According to proposes of the Cochrane Handbook for Systematic Reviews. The resulting $\mathrm{OR}$ in the fixed-effect model was 1.12 (95\% CI 1.03-1.21), OR for each sex was in the fixed-effect model 1.20 (95\% CI 1.06-1.35) in males and in the randomeffect model 1.21 (95\% CI 0.92-1.59) in females. The results of this meta-analysis indicate that cigarette smoking as an isolated factor may contribute to the development of sarcopenia. However, the results of the individual studies were largely inconsistent due to different approaches of measuring the main variables which affected the results.
\end{abstract}

\section{Key words}

Smokers • Non-smokers • Tobacco smoke • Risk factors

\section{Corresponding author}

E. Kohlíková, Faculty of Physical Education and Sport, Charles University, José Martího 31, 16252 Prague 6 - Veleslavín, Czech Republic. E-mail: kohlikova@ftvs.cuni.cz

\section{Introduction}

Cigarette smoking is undoubtedly among the most serious health risk behaviors in today's society. Cigarette smoking contributes to the development of many diseases; including perhaps, sarcopenia. Nevertheless, it is difficult on the basis of individual studies to confidently claim that smoking contributes to sarcopenia. Every age related condition or disease such as sarcopenia is associated with multiple causes. For the muscle wasting associated with sarcopenia, causes include chronic inflammation, stroke, rheumatism, fall-related injuries, and of course sedentary lifestyles (Evans 2010). The aforementioned notwithstanding, it is important to find out if cigarette smoking and sarcopenia are directly related as knowledge of each cause of this condition may lead to improving treatment. Although individual studies have shown that cigarette smoking should be counted among risk factors of sarcopenia (Lee et al. 2007, Landi et al. 2012), a comparative analysis of those studies has not been published, despite the fact that theoretical models of accelerated muscle loss by smoking cigarettes have been described previously. According to these models, metabolites that are assumed to be important in this process (e.g. aldehydes, reactive oxygen species, and reactive nitrogen species), and are 
components of the cigarettes smoke, enter the bloodstream and reach the skeletal muscles of smokers and there accelerate muscle wasting (Rom et al. 2012b, 2013).

In this meta-analysis the relation between cigarette smoking and sarcopenia was investigated. The objective was to determine whether cigarette smoking as a separate factor may contribute to the progressive loss of muscle mass and contribute to or cause sarcopenia. The main finding could bring new information about association between smoking and sarcopenia.

\section{Subjects and Methods}

We searched PubMed, Web of Science, EBSCO, and Science Direct for articles addressing the relationship between cigarette smoking and sarcopenia. Specifically, we looked for case-control studies that provided information about the relationship. For the full text acquisition the databases Wiley Online Library, SpringerLink, Citation Linker SFX UK, Proquest, Ovid, and Scopus were used. The same search stream was used in all databases: the term sarcopenia was searched in the titles of articles as a first step, keywords: human, epidemiology, prevalence, association, retrospective, cohort study, cigarette, smoking, smoker, non-smoker, tobacco, and risk factor were searched in all fields as a second step, both results of searching were connected and searched together in a last step. Transparently presented data about persons suffering from sarcopenia as well as healthy persons and their connection with smoking status created the criteria for including studies into the meta-analysis.

\section{Definition of sarcopenia}

Sarcopenia, a geriatric syndrome, was first defined in 1989 by Rosenberg as a decrease of muscle mass and strength with aging. Since sarcopenia was initially defined so broadly, more specific criteria have since been developed. Basically, the criteria are divided into three areas. The first involves measuring muscle mass, the second involves measuring muscle strength and the third involves assessment of physical performance. The most commonly currently used method to measure muscle mass is dual energy X-ray absorptiometry (DEXA) (Pahor et al. 2009). Nevertheless, measuring by the bioelectrical impedance analysis (BIA) has also been verified as a reliable tool (Janssen et al. 2000). Although there are alternative tools for measuring muscle strength (e.g. Biodex or Cybex), hand grip seems to be a useful method for muscle strength measurement, because it is inexpensive and easily applicable (Rantanen et al. 2002). The usual gait speed and get up and go test could be counted among the basic methods for physical performance characterization. In 2011 the European Working Group on Sarcopenia in Older People (EWGSOP) proposed an algorithm for diagnosing sarcopenia (Cruz-Jentoft et al. 2010). All three of the criteria noted above were included into the algorithm. For the purposes of that meta-analysis, the EWGSOP algorithm and muscle mass measurement by DEXA or BIA were chosen as suitable methods of sarcopenia diagnosis. Each of these methods is respected by scientific community as a relevant in the diagnostic process of sarcopenia. Sarcopenia related health status was dichotomized in many studies as sarcopenia and non sarcopenia. In other studies where sarcopenia was divided into three categories - non sarcopenia, moderate sarcopenia and severe sarcopenia, moderate and severe sarcopenia were collapsed into a single sarcopenia category for the purposes of the meta-analysis.

\section{Smoking categories}

Cigarette smoking status could be divided into a number of categories according to the amount number of cigarettes smoked daily, period of smoking in the subjects' lifetimes or current smoking habits. Therefore it was difficult in this work to find and establish optimal combination of categories. Different studies applied different method to quantify smoking status. An interview, a standardized questionnaire, an intervieweradministered questionnaire or self-report survey were done. Nevertheless, nearly every approach was based on the subjective evaluation of participants. Therefore, the assignment to categories of smokers and non-smokers could not be as objective as in the case of sarcopenia categories. We tried to find more precise data (e.g. packyears); nevertheless, it was not possible. For the purpose of this meta-analysis, the smokers without the regard to the period or intensity of cigarette smoking were included in the exposed group.

\section{Statistical analysis}

The quality rating of included articles was assessed using the Newcastle-Ottawa Quality Assessment Scale (Stang 2010). Odds ratios (OR) for the overall effect were first calculated thereafter, we calculated OR for each sex separately. In this case, OR was used to 
quantitatively describe the association between people exposed to smoking and sarcopenia. The Cochran Q statistic and $\mathrm{I}^{2}$ statistic (Higgins et al. 2003) were conducted to find out if heterogeneity was present. We also performed a sensitivity analysis to select a suitable analysis method. Finally, there was used the CochranMantel-Haenszel statistical method (Mantel and Haenszel 1959) and DerSimonian and Laird random-effects model (DerSimonian and Laird 1986). The Cochran-MantelHaenszel statistical method based on fixed-model effect values more large studies in contrast with DerSimonian and Laird random-effects model, which gives relatively the same worth to all the studies in the sample. All statistics were carried out in the Review Manager 5.3.

\section{Results}

Altogether, 988 papers were identified as potentially relevant. Of these, 12 papers $(22,515$ participants) were selected into the meta-analysis through a multiple-step selection procedure (Fig. 1). The basic information about the studies included in the metaanalysis is presented in Table 1. In the overall estimation and in the male estimation the Q statistic and $\mathrm{I}^{2}$ statistic indicated a high heterogeneity (Higgins et al. 2003). Because the results of the small studies were different from the results of the large ones, this may happen as a result of publication bias (Egger et al. 1997). Therefore, we performed a sensitivity analysis. We tried to exclude small studies which could be affected by bias and we compared the results before and after excluding. Nevertheless, those analyses did not provide any significant changes in results. Finally, there was used the fixed-effect model which the Cochrane Handbook for Systematic Reviews suggests provided the results of small studies are significantly different from the results of large studies (Higgins and Green 2008). Unlike the overall and male estimate, the female estimation showed only moderate heterogeneity. Since the one of the biggest study's (KNHANES) estimate was substantially lower than $\mathrm{OR}=1$ and the other studies estimates were around $\mathrm{OR}=1$ or a little above, we used the random-effect model, which should be more sensitive in that case. The overall OR for every study in the fixed-effect model was 1.12 (95\% CI 1.03-1.21), OR for each study separately are shown in Figure 2. In a detailed analysis for each gender in particular there were OR in the fixed-effect model 1.20 (95\% CI 1.06-1.35) in male (Fig. 3) and in the randomeffect model 1.21 (95\% CI 0.92-1.59) in female (Fig. 4). All the $\mathrm{OR}$ increase above $\mathrm{OR}=1$, therefore, if results are $\mathrm{OR}>1$, it implies difference in effect. However, heterogeneity and objectionable publication bias were found in this case.

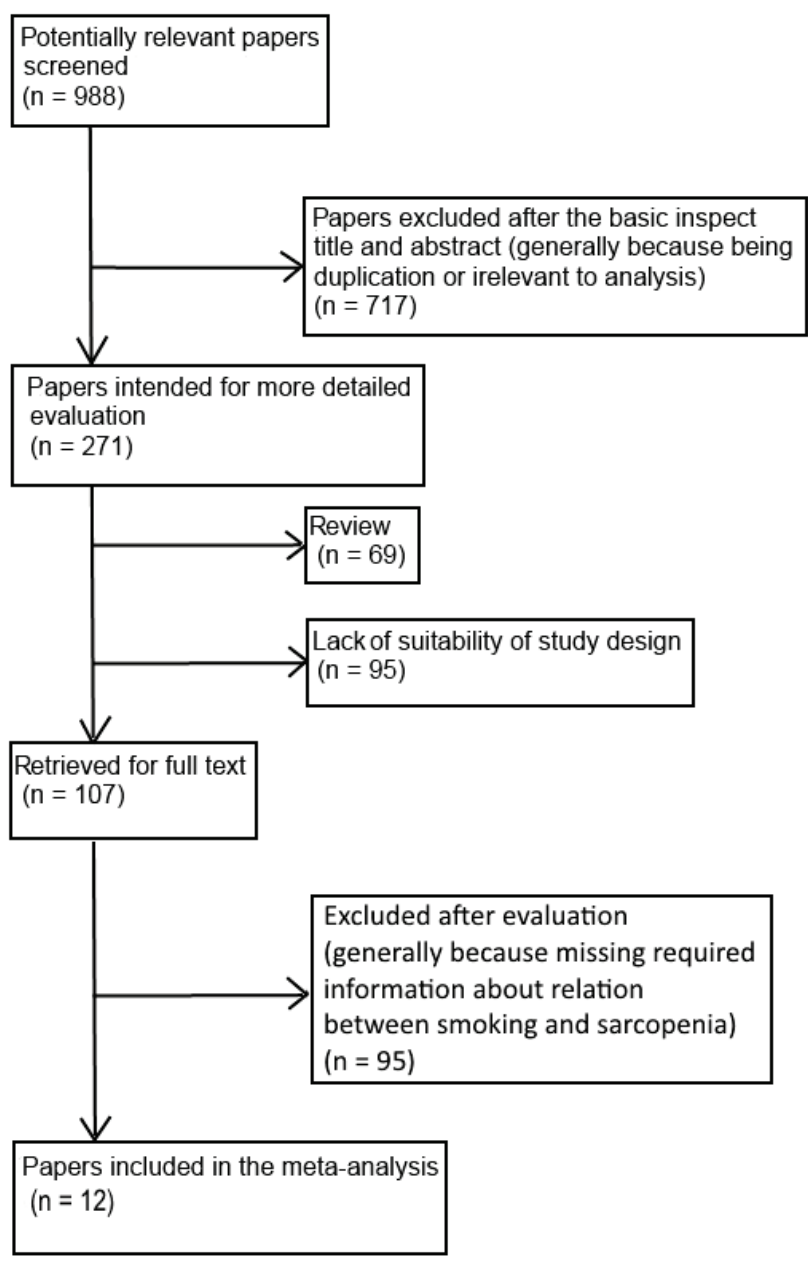

Fig. 1. Flow of information through the different phases of a systematic review.

\section{Discussion}

Sarcopenia is the multi causal syndrome whose development is influenced by many factors. Besides those that are associated with the internal environment of the organism and are largely the result of endogenous influences such as hormonal changes, increasing of proinflammatory cytokines, increased insulin resistance with aging, mitochondrial impairment, loss of repair ability, reduction in the number of motor units (Di Tano et al. 2005, Hollmann et al. 2007, Burton and Sumukadas 2010, Lang et al. 2010), there are also external risk factors which play an important role. External factors involved in the etiology of sarcopenia include poor nutrition, decreased physical activity, alcohol consuming, and also cigarette smoking (Kamel 2003, Cesari and 
Pahor 2008, Freiberger et al. 2011, Rom et al. 2012a,b). There is no doubt that cigarette smoking contributes to the development of certain diseases and, it may even contribute to the development of sarcopenia which have been suggested in some studies.

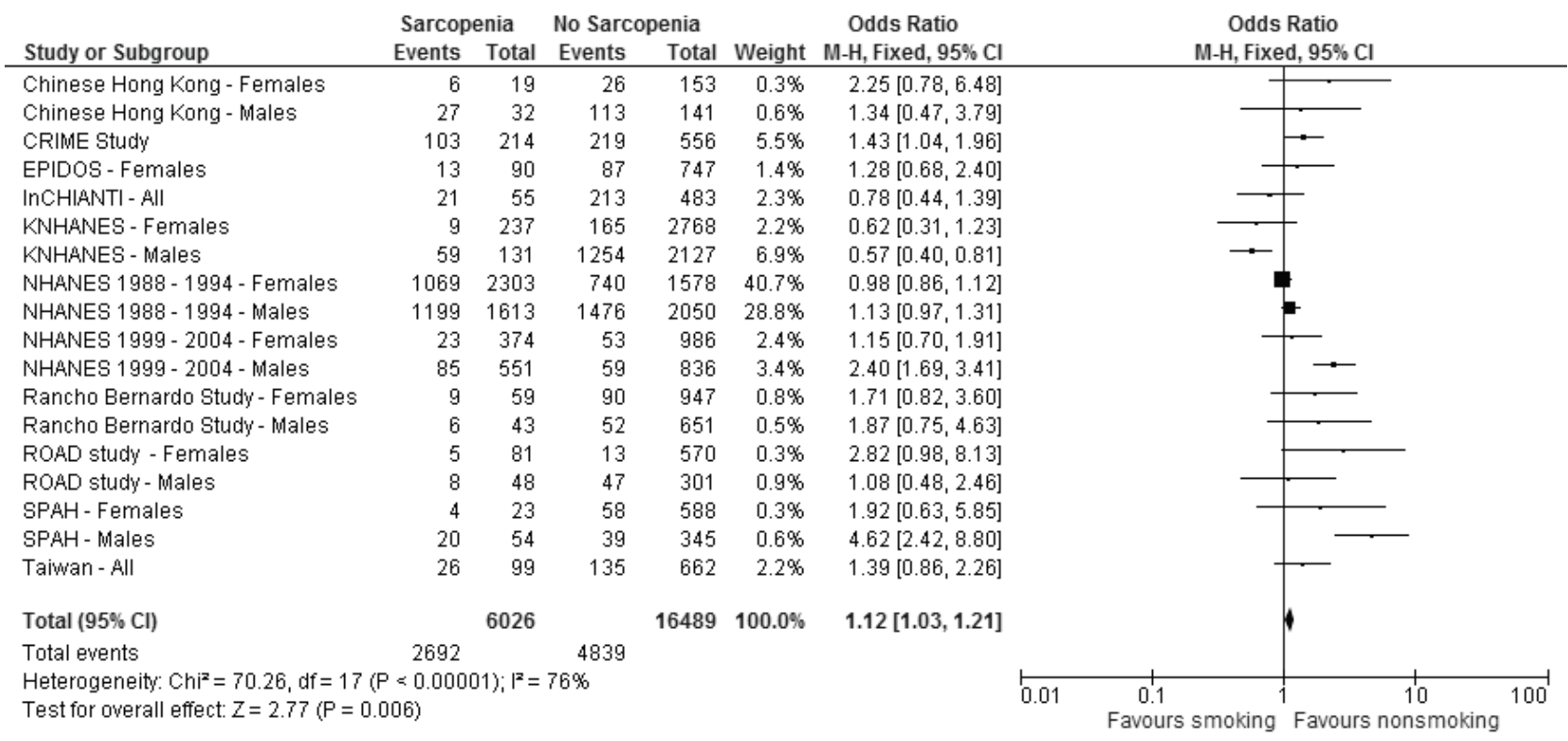

Fig. 2. A forest plot for estimating OR, the fixed-effect model and $95 \% \mathrm{CI}$ for males and females together.

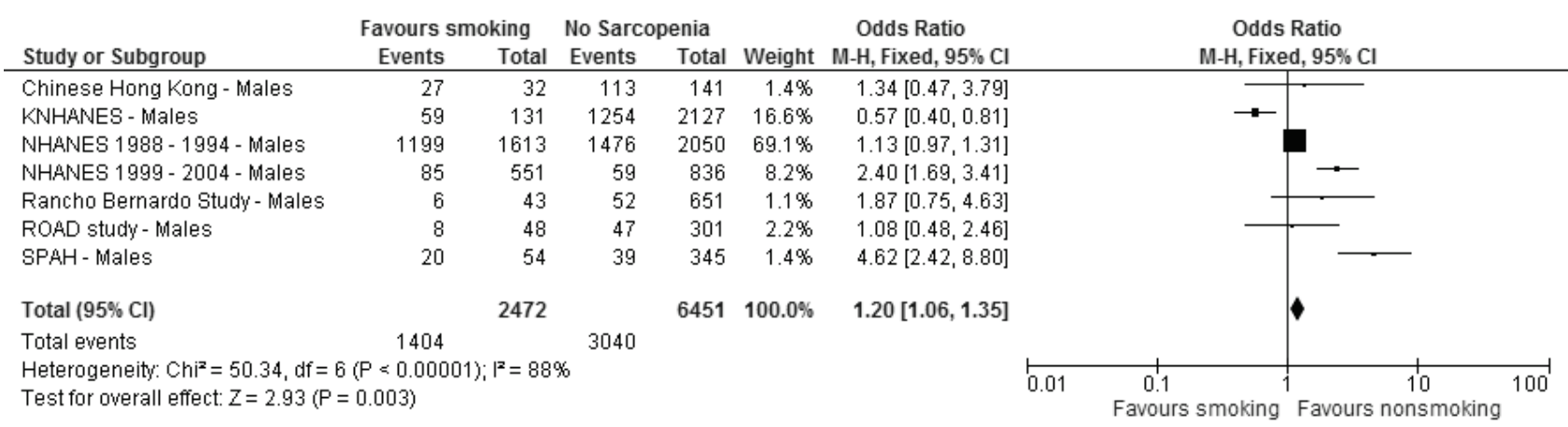

Fig. 3. A forest plot for estimating $\mathrm{OR}$, the fixed-effect model and $95 \% \mathrm{CI}$ for males.

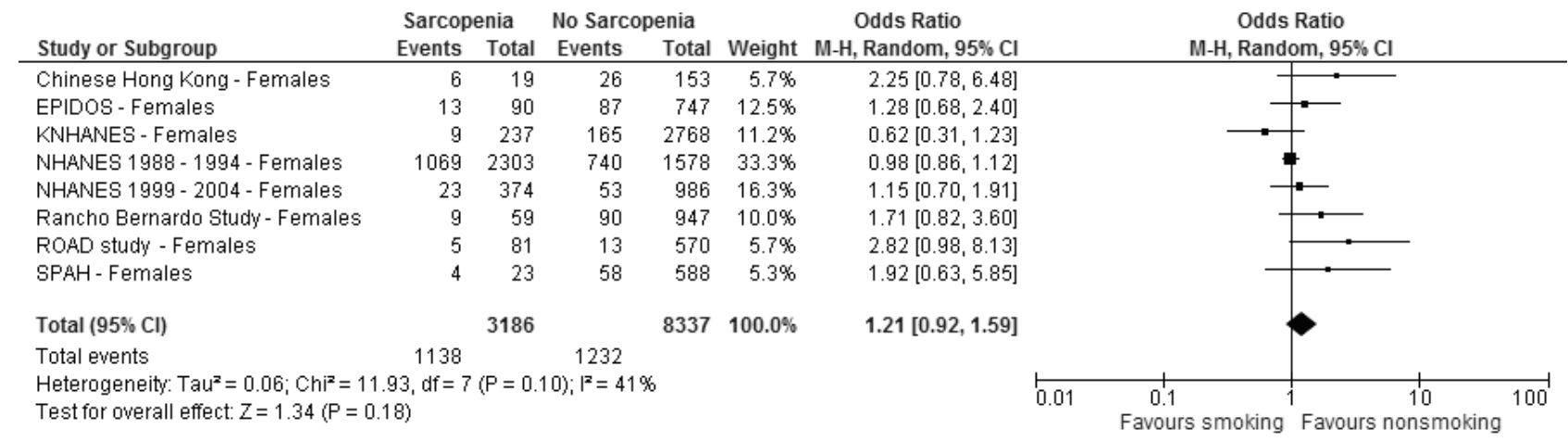

Fig. 4. A forest plot for estimating $\mathrm{OR}$, the random-effect model and $95 \% \mathrm{CI}$ in females. 
Table 1. The studies used in meta-analysis estimates.

\begin{tabular}{|c|c|c|c|}
\hline Study name & Subjects & $\begin{array}{c}\text { Definition } \\
\text { of sarcopenia }\end{array}$ & $\begin{array}{c}\text { Definition } \\
\text { of smoking categories }\end{array}$ \\
\hline $\begin{array}{l}\text { Chinese Hong Kong } \\
\text { (Lau et al. 2005) }\end{array}$ & $\begin{array}{l}\mathrm{n}=345 \\
173 \text { men and } 172 \text { women } \\
\geq 70 \text { years }\end{array}$ & $\begin{array}{l}\text { Appendicular skeletal muscle mass (ASM) } \\
\text { two standard deviations or more below the } \\
\text { normal mean for young Asian men and } \\
\text { women in this study } \\
\text { body composition by DEXA }\end{array}$ & $\begin{array}{l}\text { A standardized, } \\
\text { structured interview } \\
\text { questionnaire } \\
\text { never and current or ex- } \\
\text { smoker }\end{array}$ \\
\hline $\begin{array}{l}\text { CRIME Study } \\
\text { (Vetrano et al. 2014) }\end{array}$ & $\begin{array}{l}\mathrm{n}=770 \\
56 \% \text { women } \\
80.8 \pm 7 \text { years }\end{array}$ & $\begin{array}{l}\text { EWGSOP algorithm } \\
\text { (Cruz-Jentoft et al. 2010) } \\
\text { body composition by BIA } \\
\text { (Janssen } \text { et al. 2000) }\end{array}$ & $\begin{array}{l}\text { A standardized } \\
\text { questionnaire } \\
\text { smoker (actual/former) }\end{array}$ \\
\hline $\begin{array}{l}\text { EPIDOS } \\
\text { (Rolland et al. 2009) }\end{array}$ & $\begin{array}{l}\mathrm{n}=837 \\
\text { women } \\
>75 \text { years }\end{array}$ & $\begin{array}{l}\text { SMI of }<5.45 \mathrm{~kg} / \mathrm{m}^{2} \text { as cut off points } \\
\text { (Baumgartner } \text { et al. } 1998 \text {, Heymsfield } \text { et al. } \\
\text { 1990) } \\
\text { body composition by DEXA }\end{array}$ & $\begin{array}{l}\text { Self-reporting } \\
\text { smoking, former or } \\
\text { current }\end{array}$ \\
\hline $\begin{array}{l}\text { InCHIANTI } \\
\text { (Volpato et al. 2013) }\end{array}$ & $\begin{array}{l}\mathrm{n}=538 \\
250 \text { men and } 288 \text { women } \\
\geq 65 \text { years }\end{array}$ & $\begin{array}{l}\text { EWGSOP algorithm (Cruz-Jentoft et al. } \\
2010) \\
\text { body composition by BIA } \\
\text { (Janssen } \text { et al. } 2004 \text { ) }\end{array}$ & $\begin{array}{l}\text { Survey questions } \\
\text { never and former/current }\end{array}$ \\
\hline $\begin{array}{l}\text { KNHANES } \\
\text { (Park et al. 2013) }\end{array}$ & $\begin{array}{l}\mathrm{n}=5,263 \\
2,258 \text { men and } 3,005 \text { women } \\
>50 \text { years }\end{array}$ & $\begin{array}{l}\text { Skeletal muscle index (SMI) values in } \\
\text { KNHANES 2009-2010 participants aged } \\
18-39 \text { years corresponding to two standard } \\
\text { deviations below the mean levels were } \\
\text { used to identify sarcopenia (Janssen et al. } \\
\text { 2000, Sanada et al. 2010) } \\
\text { body composition by DEXA }\end{array}$ & $\begin{array}{l}\text { A health interview } \\
\text { never-smokers }<100 \\
\text { cigarettes in their } \\
\text { lifetimes, } \geq 100 \text { cigarettes } \\
\text { were classified as past or } \\
\text { current smokers }\end{array}$ \\
\hline $\begin{array}{l}\text { NHANES 1988-1994 } \\
\text { (Beavers et al. 2009) }\end{array}$ & $\begin{array}{l}\mathrm{n}=7,544 \\
3663 \text { men and } 3881 \text { women } \\
>40 \text { years }\end{array}$ & $\begin{array}{l}\text { Skeletal muscle mass (SMM) when is } \\
\text { within } 1 \text { and } 2 \text { resp. } 2 \text { standard deviations } \\
\text { or more below the SMM mean of a young } \\
\text { reference group that is Class I resp. Class II } \\
\text { (Janssen } \text { et al. 2002) } \\
\text { body composition by BIA }\end{array}$ & $\begin{array}{l}\text { Self-report survey } \\
\text { never/former /current }\end{array}$ \\
\hline $\begin{array}{l}\text { NHANES 1999-2004 } \\
\text { (Goodman et al. 2013) }\end{array}$ & $\begin{array}{l}\mathrm{n}=2,747 \\
1,387 \text { men and } 1,360 \text { women } \\
\geq 65 \text { years }\end{array}$ & $\begin{array}{l}\text { SMI of } 1.0 \text { SD below the mean SMI of the } \\
\text { reference population (adults aged 20-40) } \\
\text { calculated separately for males and females } \\
\text { (Heymsfield et al. 1990) } \\
\text { body composition by DEXA }\end{array}$ & $\begin{array}{l}\text { Self-reporting } \\
\text { current smoking }\end{array}$ \\
\hline $\begin{array}{l}\text { Rancho Bernardo Study } \\
\text { (Castillo et al. 2003) }\end{array}$ & $\begin{array}{l}\mathrm{n}=1,700 \\
694 \text { men and } 1006 \text { women } \\
55-98 \text { years }\end{array}$ & $\begin{array}{l}\text { Fat free mass (FFM) that is } 2.0 \text { standard } \\
\text { deviations or more below the mean of a } \\
\text { young reference group (Pichard et al. } \\
2000 \text { ) } \\
\text { body composition by BIA }\end{array}$ & $\begin{array}{l}\text { A standardized, } \\
\text { self-administered } \\
\text { questionnaire } \\
\text { current/not current }\end{array}$ \\
\hline $\begin{array}{l}\text { ROAD study } \\
\text { (Akune et al. 2013) }\end{array}$ & $\begin{array}{l}\mathrm{n}=1,000 \\
349 \text { men and } 651 \text { women } \\
\geq 65 \text { years }\end{array}$ & $\begin{array}{l}\text { EWGSOP algorithm (Cruz-Jentoft et al. } \\
2010 \text { ) } \\
\text { SMI of }<7.0 \mathrm{~kg} / \mathrm{m}^{2} \text { in males and } \\
<5.8 \mathrm{~kg} / \mathrm{m}^{2} \text { in females as cut off points } \\
\text { (Tanimoto et al. } 2012 \text { ) } \\
\text { body composition by BIA }\end{array}$ & $\begin{array}{l}\text { An interviewer- } \\
\text { administered } \\
\text { questionnaire } \\
\text { smoking/no smoking }\end{array}$ \\
\hline $\begin{array}{l}\text { SPAH } \\
\text { (Domiciano et al. 2013, } \\
\text { Figueiredo et al. 2013) }\end{array}$ & $\begin{array}{l}\mathrm{n}=1,010 \\
399 \text { men } 72.71 \pm 5.06 \text { and } 611 \\
\text { women } \\
73.22 \pm 5.21 \text { years }\end{array}$ & $\begin{array}{l}\text { SMI of }<7.26 \mathrm{~kg} / \mathrm{m}^{2} \text { in males and } \\
<5.45 \mathrm{~kg} / \mathrm{m}^{2} \text { in females as cut off points } \\
\text { (Baumgartner et al. } 1998 \text {, Newman et al. } \\
\text { 2003) } \\
\text { body composition by DEXA }\end{array}$ & $\begin{array}{l}\text { A standardized } \\
\text { questionnaire } \\
\text { current smoking }\end{array}$ \\
\hline $\begin{array}{l}\text { Taiwan } \\
\text { (Lin et al. 2013) }\end{array}$ & $\begin{array}{l}n=761 \\
407 \text { men and } 354 \text { women } \\
\geq 65 \text { years }\end{array}$ & $\begin{array}{l}\text { EWGSOP algorithm } \\
\text { (Cruz-Jentoft et al. } 2010 \text { ) } \\
\text { body composition by DEXA }\end{array}$ & $\begin{array}{l}\text { Self-reporting } \\
\text { never/current/ former }\end{array}$ \\
\hline
\end{tabular}


The results of this meta-analysis suggest that if we followed only the relation between cigarette smoking and sarcopenia, the cigarette smoking may increase the chance of developing sarcopenia. However, the results could be particularly affected by a relatively small number of studies and their high heterogeneity. For example, the overall and males results were certainly affected by the Korean KNHANES studies (Park et al. 2013) mainly because the males estimation was significantly below $\mathrm{OR}=1(0.57 ; 95 \%$ CI 0.40-0.81). This means that smoking significantly decreases the risk of sarcopenia. In any case, this result could be influenced due to the design of the study, where smoking was not the main topic. However, it is still an interesting and hardly comprehensible result. On the other hand, the estimate of SPAH (Figueiredo et al. 2014) in males was significantly above $\mathrm{OR}=1(4.62 ; 95 \%$ CI 2.42-8.80). Nevertheless, the study sample was relatively small and thus influences the overall estimate only slightly. It is even worth mentioning that the results of two American studies (NHANES 1988-1994 and NHANES 1999-2004) were different in males, which could have been caused by different approach in classification of sarcopenia and smoking status.

Perhaps the other problem of this meta-analysis is that there was not distinguished distinction between the races. The majority of the total sample consisted of Americans and Koreans, while Europeans were represented only by less than $10 \%$. A few similar studies have been done in Europe - e.g. the Hertfordshire Cohort
Study (HCS) (Patel et al. 2013), Mini-Finland Health Examination Survey in Finland - longitudinal study (Stenholm et al. 2012). European Male Ageing Study (EMAS) (Tajar et al. 2013) could be counted among these European studies which focus on the relation between cigarette smoking and sarcopenia. Nevertheless, their research design was unfortunately distinctively different to the one required for the inclusion to our meta-analysis.

Based on the results of this meta-analysis, it can be concluded that cigarette smoking could have relatively little impact on the development of sarcopenia. However, results are still inconclusive. There have not been many studies performed on the relation of sarcopenia and diverse health factors yet. Nevertheless, more than the above mentioned finding is the fact that there was not used a uniform assessing method of smoking status, even though a method had been developed, such as pack-year. That method was designed by World Health Organization (WHO) in 2008. This implies a need for more research on the relation of smoking and sarcopenia more properly designed studies.

\section{Conflict of Interest}

There is no conflict of interest.

\section{Acknowledgements}

This research project is supported by the grant NT11325 of the Ministry of Health of the Czech Republic, Specific Academic Research SVV 2014-260115 and project P 38.

\section{References}

AKUNE T, MURAKI S, OKA H, TANAKA S, KAWAGUCHI H, NAKAMURA KYOSHIMURA N: Exercise habits during middle age are associated with lower prevalence of sarcopenia: the ROAD study. Osteoporos Int 25 : 1081-1088, 2014.

BEAVERS KM, BEAVERS DP, SERRA MC, BOWDEN RG, WILSON RL: Low relative skeletal muscle mass indicative of sarcopenia is associated with elevations in serum uric acid levels: findings from NHANES III. J Nutr Health Aging 13: 177-182, 2009.

BAUMGARTNER RN, KOEHLER KM, GALLAGHER D, ROMERO L, HEYMSFIELD SB, ROSS RR, GARRY PJLINDEMAN RD: Epidemiology of sarcopenia among the elderly in New Mexico. Am J Epidemiol 147: 755-763, 1998.

BURTON LA, SUMUKADAS D: Optimal management of sarcopenia. Clin Interv Aging 5: 217-228, 2010.

CASTILLO EM, GOODMAN-GRUEN D, KRITZ-SILVERSTEIN D, MORTON DJ, WINGARD DL, BARRETTCONNOR E: Sarcopenia in elderly men and women: The Rancho Bernardo study. Am J Prev Med 25: 226-231, 2003.

CESARI M, PAHOR M: Target population for clinical trials on sarcopenia. J Nutr Health Aging 12: 470-478, 2008.

CRUZ-JENTOFT AJ, BAEYENS JP, BAUER JM, BOIRIE Y, CEDERHOLM T, LANDI F, MARTIN FC, MICHEL JP, ROLLAND Y, SCHNEIDER SM, TOPINKOVA E, VANDEWOUDE M, ZAMBONI M: Sarcopenia: European consensus on definition and diagnosis: Report of the European Working Group on Sarcopenia in Older People. Age Ageing 39: 412-423, 2010. 
DERSIMONIAN R, LAIRD N: Meta-analysis in clinical trials. Control Clin Trials 7: 177-187, 1986.

Di TANO G, FULLE S, PIETRANGELO T, BELLOMO R, FANÒ G: Sarcopenia: characteristics, genesis, remedies. Sport Sci Health 1: 69-74, 2005.

DOMICIANO DS, FIGUEIREDO CP, LOPES JB, CAPARBO VF, TAKAYAMA L, MENEZES PR, BONFA EPEREIRA RM: Discriminating sarcopenia in community-dwelling older women with high frequency of overweight/obesity: the Sao Paulo Ageing \& Health Study (SPAH). Osteoporos Int 24: 595-603, 2013.

EGGER M, DAVEY SMITH G, SCHNEIDER M, MINDER C: Bias in meta-analysis detected by a simple, graphical test. BMJ 315: 629-634, 1997.

EVANS WJ: Skeletal muscle loss: cachexia, sarcopenia, and inactivity. Am J Clin Nutr 91: 1123S-1127S, 2010.

FIGUEIREDO CP, DOMICIANO DS, LOPES JB, CAPARBO VF, SCAZUFCA M, BONFA E, PEREIRA RM: Prevalence of sarcopenia and associated risk factors by two diagnostic criteria in community-dwelling older men: the Sao Paulo Ageing \& Health Study (SPAH). Osteoporos Int 25: 589-596, 2014.

FREIBERGER E, SIEBER C, PFEIFER K: Physical activity, exercise, and sarcopenia - future challenges. Wien Med Wochenschr 161: 416-425, 2011.

GOODMAN MJ, GHATE SR, MAVROS P, SEN S, MARCUS RL, JOY E, BRIXNER DI: Development of a practical screening tool to predict low muscle mass using NHANES 1999-2004. J Cachexia Sarcopenia Muscle 4: 187-197, 2013.

HEYMSFIELD SB, SMITH R, AULET M, BENSEN B, LICHTMAN S, WANG J, PIERSON RN JR: Appendicular skeletal muscle mass: measurement by dual-photon absorptiometry. Am J Clin Nutr 52: 214-218, 1990.

HIGGINS JPT, GREEN S: Cochrane Handbook for Systematic Reviews of Interventions (Wiley Cochrane Series). Wiley-Blackwell, Hoboken, New Jersey, 2008.

HIGGINS JPT, THOMPSON SG, DEEKS JJ, ALTMAN DG: Measuring inconsistency in meta-analyses. $B M J$ 327: 557-560, 2003.

HOLLMANN W, STRÜDER HK, TAGARAKIS CVM, KING G: Physical activity and the elderly. Eur J Cardiovasc Prev Rehabil 14: 730-739, 2007.

JANSSEN I, HEYMSFIELD SB, BAUMGARTNER RN, ROSS R: Estimation of skeletal muscle mass by bioelectrical impedance analysis. J Appl Physiol 89: 465-471, 2000.

JANSSEN I, HEYMSFIELD SB, ROSS R: Low relative skeletal muscle mass (sarcopenia) in older persons is associated with functional impairment and physical disability. J Am Geriatr Soc 50: 889-896, 2002.

JANSSEN I, BAUMGARTNER RN, ROSS R, ROSENBERG IH, ROUBENOFF R: Skeletal muscle cutpoints associated with elevated physical disability risk in older men and women. Am J Epidemiol 159: 413-421, 2004.

KAMEL HK: Sarcopenia and aging. Nutr Rev 61: 157-167, 2003.

LANDI F, LIPEROTI R, FUSCO D, MASTROPAOLO S, QUATTROCIOCCHI D, PROIA A, RUSSO A, BERNABEI R, ONDER G: Prevalence and risk factors of sarcopenia among nursing home older residents. J Gerontol A Biol Sci Med Sci 67: 48-55, 2012.

LANG T, STREEPER T, CAWTHON P, BALDWIN K, TAAFFE DR, HARRIS TB: Sarcopenia: etiology, clinical consequences, intervention, and assessment. Osteoporos Int 21: 543-559, 2010.

LAU EM, LYNN HS, WOO JW, KWOK TC, MELTON LJ 3RD: Prevalence of and risk factors for sarcopenia in elderly Chinese men and women. J Gerontol A Biol Sci Med Sci 60: 213-216, 2005.

LEE JS, AUYEUNG TW, KWOK T, LAU EM, LEUNG PC, WOO J: Associated factors and health impact of sarcopenia in older chinese men and women: a cross-sectional study. Gerontology 53: 404-410, 2007.

LIN CC, LIN WY, MENG NH, LI CI, LIU CS, LIN CH, CHANG CK, LEE YD, LEE CC, LI TC: Sarcopenia prevalence and associated factors in an elderly Taiwanese metropolitan population. J Am Geriatr Soc 61: 459-462, 2013.

MANTEL N, HAENSZEL W: Statistical aspects of the analysis of data from retrospective studies of disease. $J$ Natl Cancer Inst 22: 719-748, 1959.

NEWMAN AB, KUPELIAN V, VISSER M, SIMONSICK E, GOODPASTER B, NEVITT M, KRITCHEVSKY SB, TYLAVSKY FA, RUBIN SM, HARRIS TB, HEALTH ABC STUDY INVESTIGATORS: Sarcopenia: alternative definitions and associations with lower extremity function. J Am Geriatr Soc 51: 1602-1609, 2003.

PAHOR M, MANINI T, CESARI M: Sarcopenia: clinical evaluation, biological markers and other evaluation tools. J Nutr Health Aging 13: 724-728, 2009. 
PARK S, HAM JO, LEE BK: A positive association of vitamin D deficiency and sarcopenia in 50 year old women, but not men. Clin Nutr 33: 900-905, 2014.

PATEL HP, SYDDALL HE, JAMESON K, ROBINSON S, DENISON H, ROBERTS HC, EDWARDS M, DENNISON E, COOPER C, AIHIE SAYER A: Prevalence of sarcopenia in community-dwelling older people in the UK using the European Working Group on Sarcopenia in Older People (EWGSOP) definition: findings from the Hertfordshire Cohort Study (HCS). Age Ageing 42: 378-384, 2013.

PICHARD C, KYLE UG, BRACCO D, SLOSMAN DO, MORABIA A, SCHUTZ Y: Reference values of fat-free and fat masses by bioelectrical impedance analysis in 3393 healthy subjects. Nutrition 16: 245-254, 2000.

RANTANEN T, AVLUND K, SUOMINEN H, SCHROLL M, FRANDIN K, PERTTI E: Muscle strength as a predictor of onset of ADL dependence in people aged 75 years. Aging Clin Exp Res 14: 10-15, 2002.

ROLLAND Y, LAUWERS-CANCES V, CRISTINI C, ABELLAN VAN KAN G, JANSSEN I, MORLEY JE, VELLAS B: Difficulties with physical function associated with obesity, sarcopenia, and sarcopenic-obesity in community-dwelling elderly women: the EPIDOS (EPIDemiologie de l'OSteoporose) Study. Am J Clin Nutr 89: 1895-1900, 2009.

ROM O, KAISARI S, AIZENBUD D, REZNICK AZ: Lifestyle and sarcopenia-etiology, prevention, and treatment. Rambam Maimonides Med J 3: e0024, 2012a.

ROM O, KAISARI S, AIZENBUD D, REZNICK AZ: Sarcopenia and smoking: a possible cellular model of cigarette smoke effects on muscle protein breakdown. Ann N Y Acad Sci 1259: 47-53, 2012 b.

ROM O, KAISARI S, AIZENBUD D, REZNICK AZ: The effects of acetaldehyde and acrolein on muscle catabolism in C2 myotubes. Free Radic Biol Med 65C: 190-200, 2013.

ROSENBERG IH: Epidemiologic and methodologic problems in determining nutritional-status of older persons proceedings of a conference held in Albuquerque, New Mexico, October 19-21, 1988 - Summary Comments. Am J Clin Nutr 50: 1231-1233, 1989.

SANADA K, MIYACHI M, TANIMOTO M, YAMAMOTO K, MURAKAMI H, OKUMURA S, GANDO Y, SUZUKI K, TABATA I, HIGUCHI M: A cross-sectional study of sarcopenia in Japanese men and women: reference values and association with cardiovascular risk factors. Eur J Appl Physiol 110: 57-65, 2010.

STANG A: Critical evaluation of the Newcastle-Ottawa scale for the assessment of the quality of nonrandomized studies in meta-analyses. Eur J Epidemiol 25: 603-605, 2010.

STENHOLM S, TIAINEN K, RANTANEN T, SAINIO P, HELIOVAARA M, IMPIVAARA O, KOSKINEN S: Longterm determinants of muscle strength decline: prospective evidence from the 22-year mini-Finland follow-up survey. J Am Geriatr Soc 60: 77-85, 2012.

TAJAR A, LEE DM, PYE SR, O'CONNELL MD, RAVINDRARAJAH R, GIELEN E, BOONEN S, VANDERSCHUEREN D, PENDLETON N, FINN JD, BARTFAI G, CASANUEVA FF, FORTI G, GIWERCMAN A, HAN TS, HUHTANIEMI IT, KULA K, LEAN ME, PUNAB M, WU FC, O'NEILL TW: The association of frailty with serum 25-hydroxyvitamin D and parathyroid hormone levels in older European men. Age Ageing 42: 352-359, 2013.

TANIMOTO Y, WATANABE M, SUN W, SUGIURA Y, TSUDA Y, KIMURA M, HAYASHIDA I, KUSABIRAKI T, KONO K: Association between sarcopenia and higher-level functional capacity in daily living in community-dwelling elderly subjects in Japan. Arch Gerontol Geriatr 55: e9-e13, 2012.

VETRANO DL, LANDI F, VOLPATO S, CORSONELLO A, MELONI E, BERNABEI R, ONDER G: Association of sarcopenia with short- and long-term mortality in older adults admitted to acute care wards: results from the CRIME Study. J Gerontol A Biol Sci Med Sci 69: 1154-1161, 2014.

VOLPATO S, BIANCHI L, CHERUBINI A, LANDI F, MAGGIO M, SAVINO E, BANDINELLI S, CEDA GP, GURALNIK JM, ZULIANI G, FERRUCCI L: Prevalence and clinical correlates of sarcopenia in communitydwelling older people: application of the EWGSOP definition and diagnostic algorithm. J Gerontol A Biol Sci Med Sci 69: 438-446, 2014.

WORLD HEALTH ORGANIZATION: WHO Report on the Global Tobacco Epidemic 2008: The MPOWER Package. World Health Organization, Geneva, 2008, ISBN 92-4-159628-7. 